\title{
Engineering Aquaculture in Rural Haiti: A Case Study
}

\author{
Aaron Gordon \\ Glenn Department of Civil Engineering \\ Clemson University \\ asgordo@g.clemson.edu \\ Guy Higdon \\ Glenn Department of Civil Engineering \\ Clemson University \\ ghh@g.clemson.edu
}

\author{
Jeffery Plumblee \\ Department of Engineering Leadership \& \\ Program Management \\ The Citadel \\ jplumble@citadel.edu \\ Ian Davis \\ John E. Walker Department of Economics \\ Clemson University \\ ijdavis@g.clemson.edu
}

\author{
David Vaughn \\ Glenn Department of Civil Engineering \\ Clemson University \\ dev@clemson.edu
}

\begin{abstract}
Large commercial and small scale aquaculture programs have been attempted in Haiti with mixed results. This paper examines a case study where a grassroots Haitian organization worked with American engineers and university students to design and construct simple infrastructure to augment their hatchery. This small investment has also encouraged other Haitians to open up aquaculture programs, independent of international intervention, that utilize this new infrastructure. The practices and partnership exhibited in this case study can be replicated with similar outcomes for local enterprises and businesses. Other university programs can also partner with these local conglomerates, providing valuable experiences for the students. Aquaculture still has many obstacles, but many infrastructure challenges can be overcome through such synergies.
\end{abstract}

Index Terms - aquaculture, Haiti, Central Plateau, tilapia, bridge

\section{INTRODUCTION}

Fish farming, the husbandry of aquatic organisms, is a subset of aquaculture and one of the world's fastest growing food industries in both developed and developing regions. ${ }^{1}$ However, aquaculture is a highly sensitive enterprise and involves several crucial factors in order to flourish, including an appropriate business market and basic knowledge of fish. ${ }^{2}$ A primary issue found in many aquaculture programs involves a lack of infrastructure such as efficient hatcheries that provide fingerlings to farmers and effective transportation of the fish to market. ${ }^{3,4}$ Aquaculture is widely considered to be an underutilized and underappreciated industry in the developing world. A successful aquaculture program has the ability to not only provide jobs and income to combat poverty but also address several key nutritional and health problems such as protein deficiency and protection against cardiovascular disease. ${ }^{5,6}$ These programs also promote 
International Journal for Service Learning in Engineering, Humanitarian Engineering and Social Entrepreneurship Vol. 12, No. 2, pp. 15-33, Fall 2017

ISSN 1555-9033

economic development in the region, as evidenced by programs in Sub-Saharan Africa, and bolster regional food security, as evidenced by programs in Asia. ${ }^{7,8}$ Fisheries and aquaculture development align with several of the United Nations' Sustainable Development Goals (SDGs) by helping improve nutrition, food security, and sustainable economic development in developing countries. ${ }^{9}$

This paper provides an overview of fish farming efforts in Haiti, its triumphs and shortcomings, and then provides details on a particular case study in Haiti's rural Central Plateau. By leveraging resources from several non-governmental organizations (NGOs), a university-based service-learning organization worked with a local Haitian entrepreneurial organization to achieve a successful aquaculture hatchery. This operation has inspired other local people to establish their own enterprises and aquaculture facilities. It was found that providing a small initial investment of infrastructure and training enabled aquaculture to take root in the region, fostering job creation and poverty alleviation.

In conjunction with aid organizations similar to those mentioned in this paper, many large entities including the Organization of the Petroleum Exporting Countries (OPEC) development and the European Union have funded and continue to show interest in projects dedicated to scaling up aquaculture in Haiti. ${ }^{10}$ Furthermore, increased attention is being called to governments across Latin America and the Caribbean to begin providing financial assistance schemes and subsidies to spur growth of the industry. ${ }^{11}$

This service-learning organization used technical expertise from both aquaculture and engineering professionals to assist with the construction of a hatchery within Haiti's lowresource settings and with materials predominantly found in the Central Plateau. The resilient and safe construction practices used can be replicated by service-learning programs and NGOs around Haiti and other rural areas in developing countries to realize similar positive outcomes.

\section{BACKGROUND}

\section{Aquaculture in Haiti}

Haiti, a small Caribbean nation of approximately 10 million people, is the poorest country in the Western Hemisphere. According to World Bank Classifications, one half of Haitians live in poverty and one quarter live in extreme poverty. These indicators are even worse in rural areas where three quarters of Haitians live in poverty, and one half live in extreme poverty. ${ }^{12}$ Over $90 \%$ of Haitians living in rural regions engage in agricultural practices but only $4 \%$ of households utilize fisheries or aquaculture. ${ }^{13}$ Most of these fisheries in Haiti are small-scale, non-commercial, and subsistent. ${ }^{14}$ Yet, introducing more sustainable methods of aquaculture through fish hatcheries and proper practices can enable farmers to improve productivity, increase product value, and create a viable market response. ${ }^{15}$ Fisheries have the potential to fulfil some of Haiti's most pressing needs: stable economic growth and food security. ${ }^{16}$

Commercial aquaculture at scale still has not reached Haiti, and its per capita consumption of fish of $4.5 \mathrm{~kg} /$ year is still well short of the global average of $18 \mathrm{~kg} / \mathrm{year}$ and short of the Caribbean average of $9.4 \mathrm{~kg} /$ year. ${ }^{17,18}$ The culture of Haiti, and many developing countries, can challenge the culture of aquaculture. Effective economic development requires a gradual flow of income over time, as opposed to sporadic employment. Harvesting fish usually entails one large, 
periodic sum of income which requires long-term planning and production in order to create and sustain a livelihood. These issues have been seen in the past with marine cages in Haiti's northern coast where Haitians struggled to resourcefully manage their new assets. ${ }^{19}$

With hopes of stimulating the fishing industry in the country, tilapia mossambica was introduced in the 1950s by the United Nations Food and Agriculture Organization. ${ }^{20}$ This hearty species of tilapia is able to survive in relatively harsh climates even in the most remote regions of Haiti. ${ }^{21}$ In fact, tilapia have been cultured in tropical areas for decades since their food source, plankton and debris, is readily available. ${ }^{22}$ Unfortunately, poor dissemination of education, lack of fishery infrastructure, and a general scarcity of resources for this particular program precluded aquaculture from truly ameliorating the country's economic and nutritional woes. ${ }^{23}$

Several aquaculture programs and hatcheries have appeared in Haiti following the devastating 2010 earthquake. Such efforts have included a massive hatchery in Santo (near Portau-Prince) funded and operated by Operation Blessing (OB) with support from Partners in Health (PIH) that was completed in 2013. Through a partnership with Aquasafra, Inc., this hatchery has the capacity to produce millions of tilapia fingerlings every year for private Haitian farmers, NGOs, and the government, which could promote economic development and job growth. Focusing on silver tilapia, the OB hatchery sends bags of the tilapia seed across the entire country according to Operation Blessings website as of September 2016. Despite such efforts, aquaculture in Haiti has not yet garnered local entrepreneurs and the costs of maintaining a subsistent, non-commercial fish farm still outweigh its benefits. This trend is seen in a study conducted by Landell Mills, funded by the European Union. Figure 1 displays that despite major investments in Haitian aquaculture, there has been subdued growth. Outside of this Landell Mills study, there has been very little documentation and literature about the effectiveness of many of these programs, and communication between aquaculture initiatives has been lacking. ${ }^{24}$

\section{Production aquacole HAÏTI}

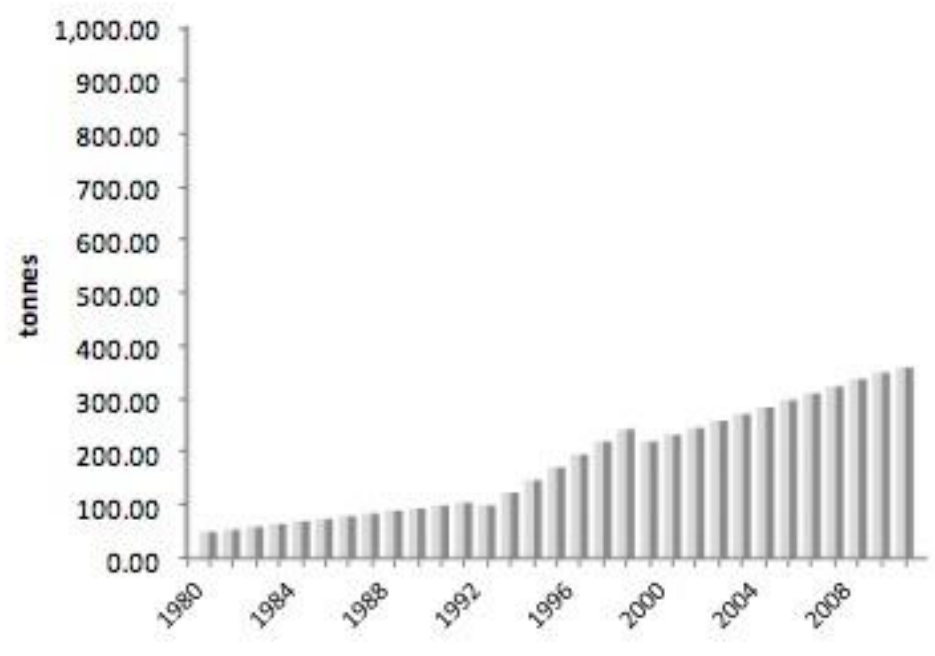

FIGURE 1

TRANSLATION: HAITIAN AQUACULTURE PRODUCTION IN TONS FROM 1980 TO $2012 .{ }^{25}$ 
International Journal for Service Learning in Engineering, Humanitarian Engineering and Social Entrepreneurship Vol. 12, No. 2, pp. 15-33, Fall 2017

ISSN 1555-9033

\section{Aquaculture on Lake Peligre}

Lake Peligre, a large man-made lake in Haiti's mountainous Central Plateau, is one of the best sites in the country for developing pond aquaculture due to its clay-like soils and available land. ${ }^{26}$ In a 1973 assessment, it was noted that the Haitian government and USAID budgeted $\$ 14,000$ for the establishment of an aquaculture co-op on Lake Peligre. ${ }^{27}$ It is not clear whether this budget was approved, and a UN report from 1980 indicated that no information was available concerning fish production in Lake Peligre. ${ }^{28}$ In 1998, a bulletin by the European Commission detailed a development project for aquaculture around Lake Peligre by the Faculté d'Agronomie et de Médecine Vétérinaire (FAMV). This year-long program started in September 1997 and sought to bolster local fishing enterprises by providing fishing equipment and materials but encountered issues with the community in Peligre due to specious rumors involving taxation and the privatization of the lake. ${ }^{29}$

A joint effort by Caribbean Harvest, an NGO run by an African entrepreneur, sought to engender aquaculture around Lake Peligre in 2010. Through a generous grant from the Clinton Foundation and support from PIH, a hatchery was constructed on the Boucan-Carre River in the Central Plateau, according to the Clinton Foundation website as of September $2016 .{ }^{30}$ Upon its completion in 2012, the hatchery boasted the capacity to provide fingerling tilapia to farmers on Lake Azuie and Lake Peligre (Haiti's two largest lakes) in an effort to promote economic development and create new jobs for families in the area according to Heifer International's website. At the time, Caribbean Harvest stated that $\$ 2,200$ was needed to put two tilapia cages in one of these lakes which creates one job for a Haitian. Heifer International, a large international NGO based in the United States, supported the project by donating free cages to fishermen around Lake Peligre along with free training sessions. ${ }^{31}$ With fingerlings from Caribbean Harvest's new hatchery and cages from Heifer International, it was expected that about 2,000 cages would be present in Lake Peligre by 2015, translating to well over 1,000 jobs being created, according to Caribbean Harvest's website as of September 2016.

The assessment by Landell Mills investigated the technical choices by aquaculture programs around Lake Peligre. Specifically, the report questioned Caribbean Harvest's location for their aforementioned hatchery on the Boucan-Carre River, which forced them to use expensive and complex equipment, notably the solar-powered pumping and filtering system. ${ }^{32}$ The complexity of the technology has resulted in far fewer fingerlings than expected since many of the hatchery technicians lack the knowledge to fulfil the capabilities of the site. Consequently, Lake Peligre has been unable to use their fingerlings. The report noted that "almost all cages on the lake shore [of Peligre] are empty.",33

In 2013, authors of this paper spoke with several citizens around Lake Peligre and witnessed very few cages in the water. According to community members of the lakeside villages of Ba Cange and Chapoteau, the major issue with aquaculture in the Central Plateau has involved fingerlings. Haitians in the area have had cages to grow Tilapia but they lack the resources to breed the next generation of fish. Farmers referenced the efforts of Caribbean Harvest, but also noted that the lack of a readily available source of fingerlings precluded the fisherman from achieving a steady source of income for their families. Many farmers could not maintain a business solely on fingerlings from the small Caribbean Harvest hatchery in Boucan-Carre, and 
International Journal for Service Learning in Engineering, Humanitarian Engineering and Social Entrepreneurship Vol. 12, No. 2, pp. 15-33, Fall 2017

ISSN 1555-9033

logistics of getting fingerlings from the Operation Blessing Hatchery in Santo was too expensive and complex.

The aquaculture industry in this region of Haiti is impeded by the local infrastructure, namely a local and consistent source for fingerlings and a means of transportation so farmers can transport their fingerlings to their cages and then to market, despite the best efforts of multilateral institutions, large international NGOs, and local NGOs. ${ }^{34}$ Local hatcheries, situated adjacent to the aquaculture ponds and lake are much better for aquaculture practices as it allows the farmer more control over supply and quantity. ${ }^{35}$ Therefore, developing the local area and constructing a suitable hatchery could catalyse the creation of local fisheries and make a significant impact on the region.

\section{CEDC and ACEDLP}

A local entrepreneur and businessman in the area is the founding director of an agricultural co-op and Haitian NGO called 'Community Action for Education and Development of Lake Peligre' (known through its Haitian acronym: ACEDLP). Since 2005, this grassroots organization has sought to develop the region around Lake Peligre, thus benefiting local farmers and encouraging best practices. ACEDLP had been promoting aquaculture in the area for several years in conjunction with the Caribbean Harvest/Heifer International projects. However, sourcing fingerlings from outside the Central Plateau was expensive and many of the fingerlings did not survive the transport process. Despite availability of land and labor, ACEDLP lacked the financial backing to construct a proper fish hatchery to produce fingerlings locally and avoid acquiring them from Port-au-Prince.

Clemson Engineers for Developing Countries (CEDC) is a student-driven service-oriented program at Clemson University whose mission is to develop sustainable, engineered solutions with communities in the developing world. CEDC utilizes a translation-based approach by researching and then implementing engineering projects in rural Haiti. It accomplishes this though its organizational structure that fosters continuous student involvement throughout their undergraduate experience via classwork and an internship program. ${ }^{36}$ By engaging students for multiple semesters, offering biannual travel opportunities, and fostering a long-term relationship with a specific community in Haiti's Central Plateau, CEDC is able to offer students an international experience while teaching them about the greater impacts of engineering on another community. $^{37}$

One of the most successful features of CEDC, from both undergraduate education and community development perspectives, is the structured and innovative internship experience. In addition to student participation in design, planning, and project implementation, a few students are selected annually for an internship in the host community where they have the opportunity to enhance technical and professional skills while engaging with a different culture. The internship program consists of Clemson University students living in rural Haiti for 6-12 months while designing and implementing infrastructure projects in the surrounding communities. ${ }^{38}$

Clemson Engineers for Developing Countries (CEDC) has been working with multiple NGOs in the Central Plateau on a variety of projects, dating back to 2009. These projects have included renovating a school, installing water distribution and filtration systems, and partnering with a local concrete block manufacturer to improve local construction materials. ${ }^{39,40}$ Such efforts have been made possible through partnerships with industry professionals, local NGOs 
with connections to the Central Plateau, and the unique internship program which enables CEDC to have a year-round presence in Haiti. ${ }^{41}$

In 2014, CEDC interns were approached by ACEDLP to discuss options to augment aquaculture on Lake Peligre. With guidance and support from Caribbean Harvest, ACEDLP already had four ponds dug for this hatchery. They had also attempted to use a non-engineered system to construct a water line to the hatchery, but it failed due to inadequate structural support and lack of pressure head from changes in elevation. Without a reliable source of fresh water, the ponds could not function as a fish hatchery. ACEDLP requested that CEDC provide technical and engineering support to provide farmers with a source of healthy fingerlings close to the lake. In return, ACEDLP would provide the land and local labor to support the project. Capital investment for the project was secured from the Episcopal Diocese of Upper South Carolina (EDUSC), an organization with over 35-years of support and experience in the Central Plateau.

\section{METHODS AND DESIGN}

\section{Hatchery Design}

In 2011, CEDC dammed a large spring in Ba Cange, the area below Cange and next to Lake Peligre. This structure, seen in Figure 2, was built as a part of the municipal water supply system for the village of Cange. ${ }^{42}$ The spring provides a flow rate of approximately 50 cubic feet per second or about 20,000 gallons per minute depending on the time of year, thus excess water from the dam could be directed towards the ACEDLP hatchery. ${ }^{43}$ The hatchery is 10-15 feet lower in elevation than the dam, so a gravity-fed line was considered the most viable option to provide a continuous and sustained flow of water to this hatchery without necessitating a pump or electricity. Pump systems are costly and much more difficult to maintain than gravity-fed systems, and are therefore a less feasible solution for rural Haiti. ${ }^{44}$ However, elevation changes between the dam and the hatchery would require substantial trenching operations to allow a gravity system.

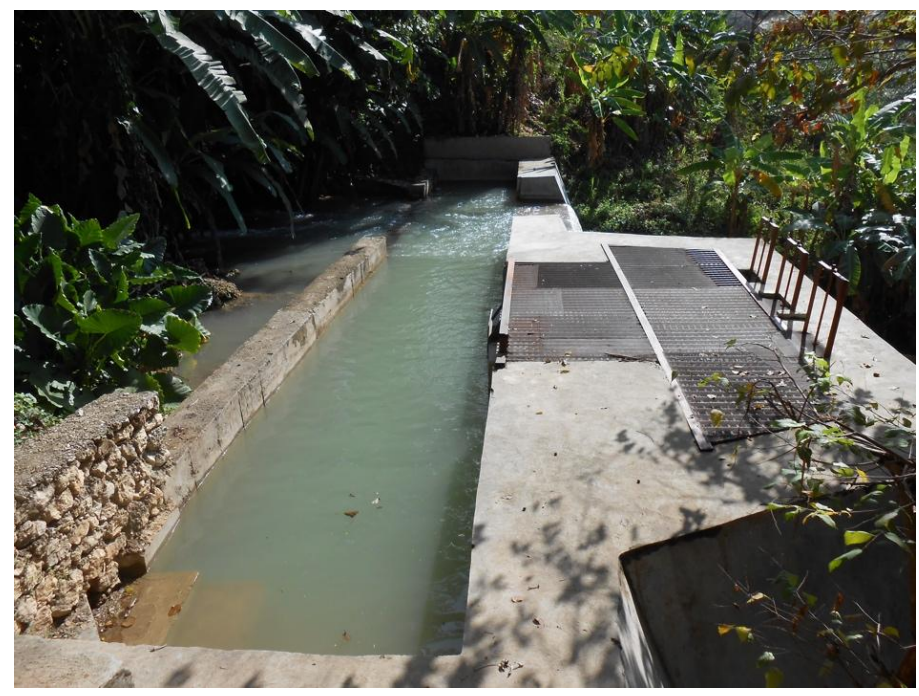

FIGURE 2

THE BA CANGe DAM 
To support the efforts of Caribbean Harvest and ACEDLP, CEDC was tasked with transporting water from the dammed spring in Ba Cange to the current location of the four ACEDLP hatchery ponds approximately 800 feet southwest of the dam. See Figure 3 for satellite imagery of the locations of the ACEDLP hatchery and the Ba Cange dam in relation to the village of Cange and National Route 3.

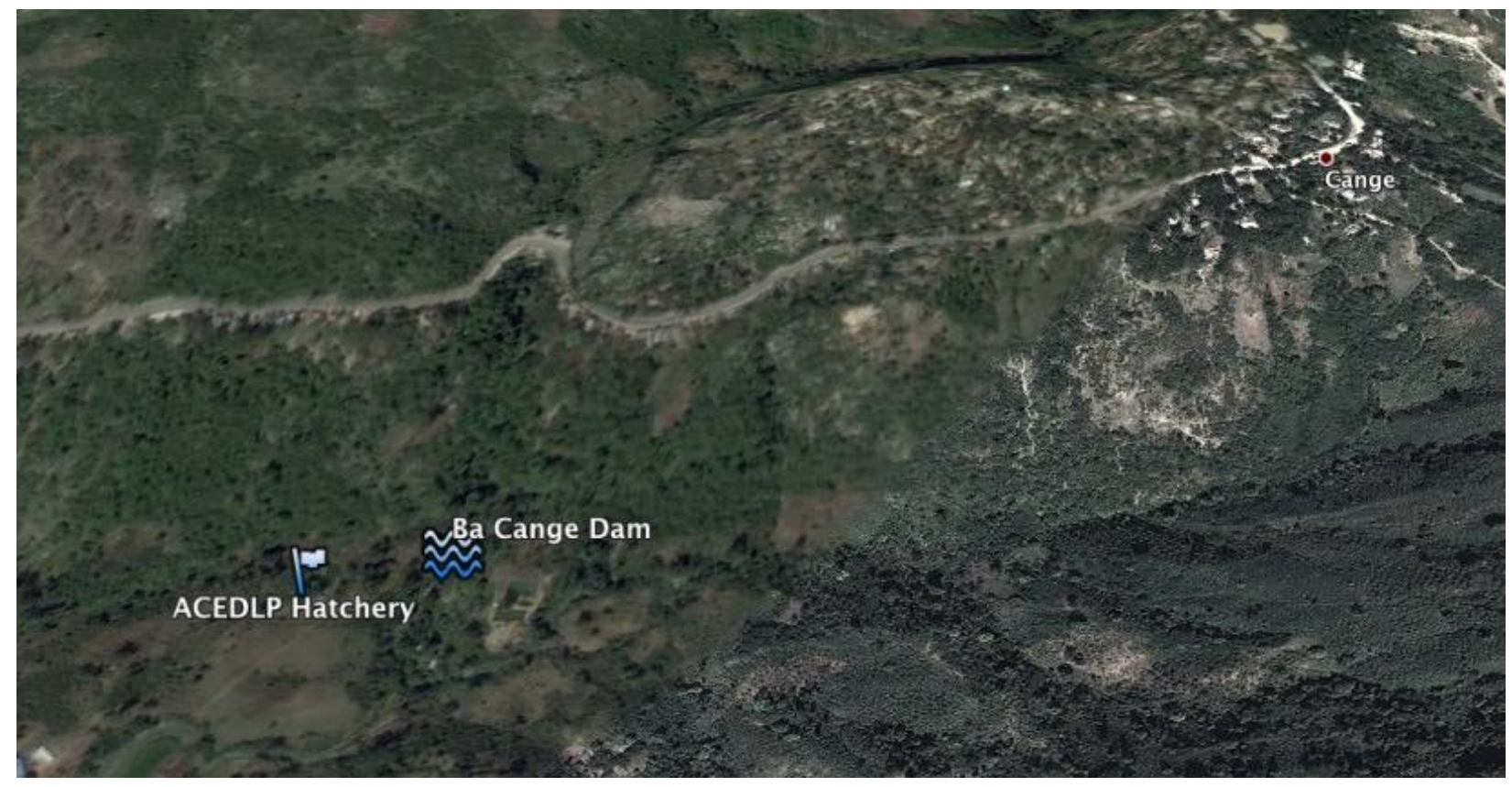

FIGURE 3

\section{SATEllite image of THE hatchery, Ba CANGe Dam, and CANGe. National Route 3 CAN Be SEEN CUTTING THROUGH THE TERRAIN ABOVE THE HATCHERY}

Three of the ponds are 1,200 square feet earthen structures, while the fourth is a 400 square feet concrete basin. Of the three earthen ponds, one is intended for the main brood stock (the mature fish utilized to breed), one is a grow-out pond where fry (newly hatched fish) can grow into fingerling size before being bought by local farmers who own cages in the lake, and the last is intended to be a commercial pond where the full-size fish can be sold for profit. An example of one of the earthen ponds can be seen in Figure 4. The final pond (see Figure 5) is made of concrete and will be used for the secondary brood stock; these fish will move to the earthen ponds as they mature. 
International Journal for Service Learning in Engineering, Humanitarian Engineering and Social Entrepreneurship Vol. 12, No. 2, pp. 15-33, Fall 2017 ISSN 1555-9033

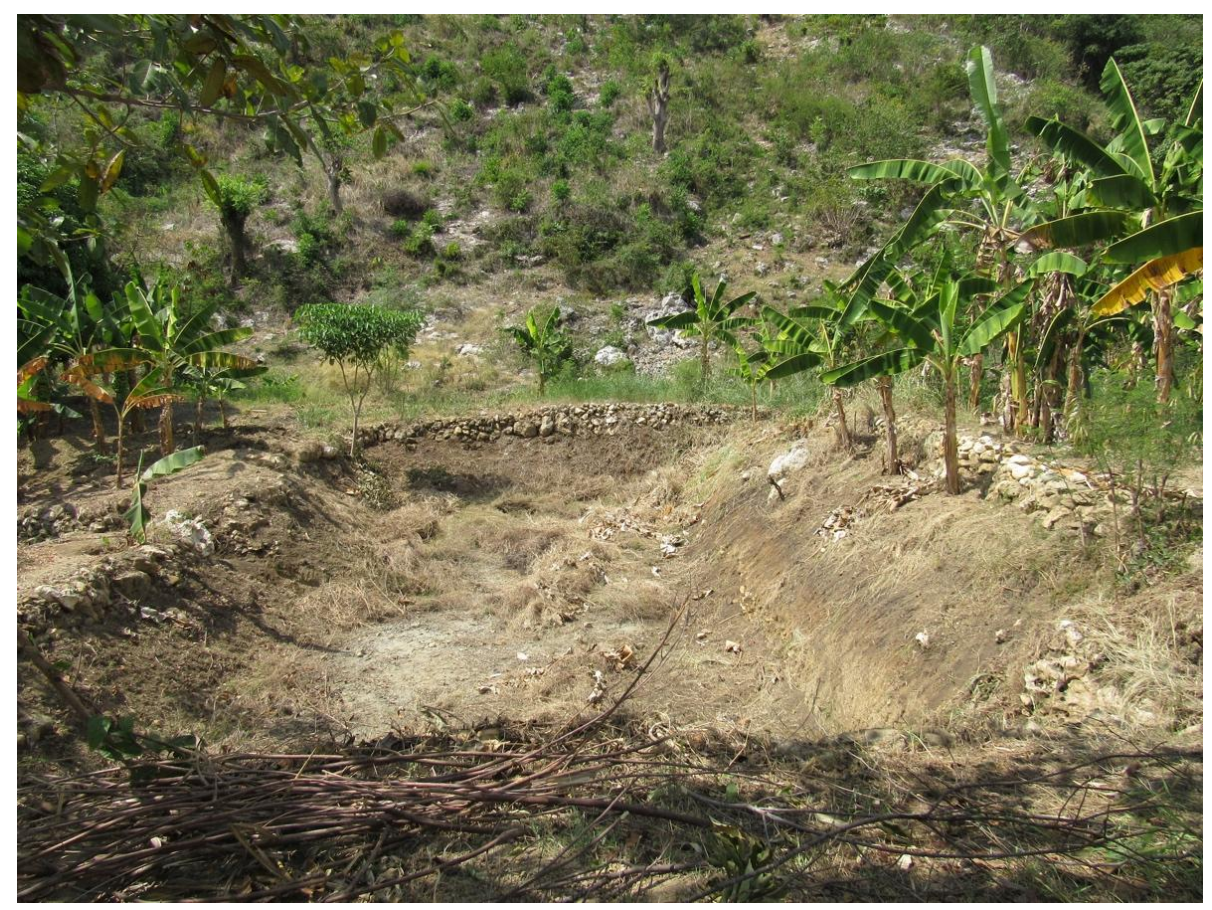

FIGURE 4

AN EMPTY EARTHEN POND AT THE ACEDLP HATCHERY

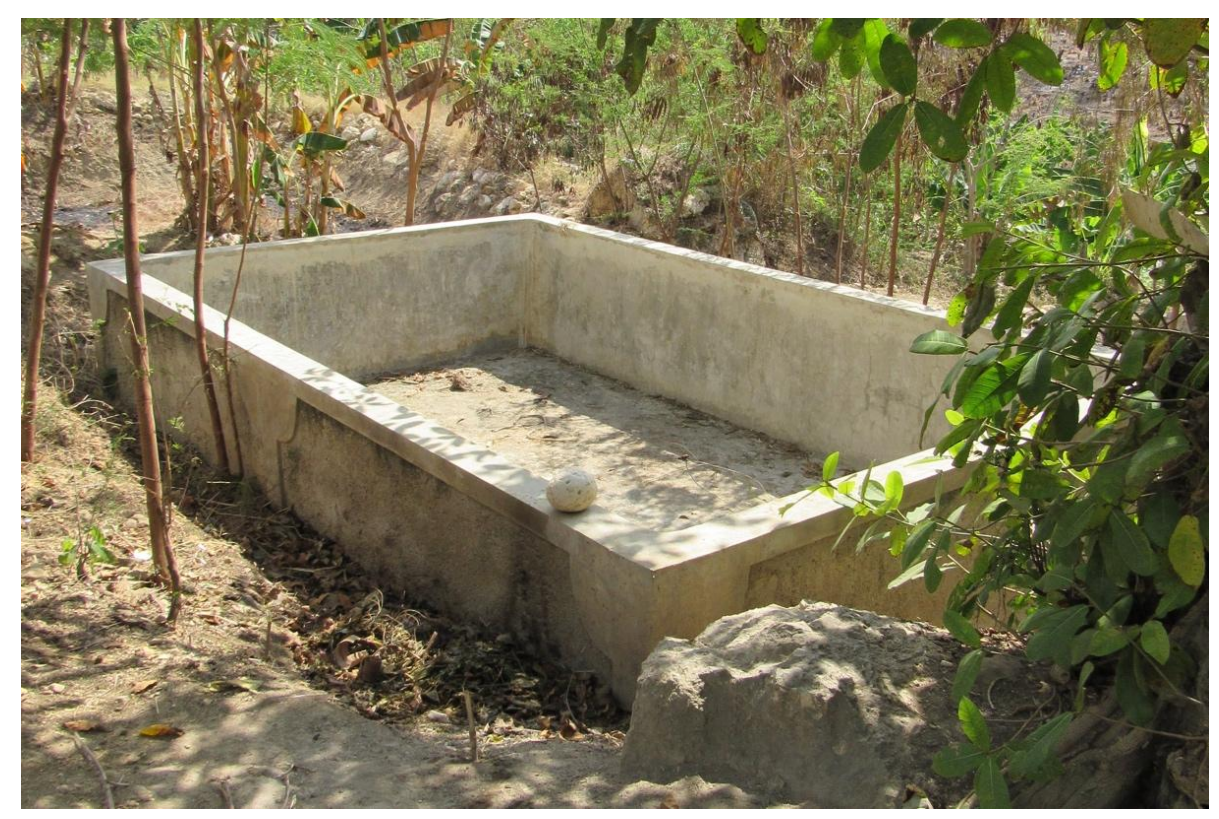

FIGURE 5

CONCRETE FISH POND AT THE ACEDLP HATCHERY 
To design the pipe layout for the hatchery, CEDC students worked with aquaculture experts from Caribbean Harvest and the local Haitians to develop a rough piping diagram to meet the needs of the enterprise. ACEDLP requested that each pond have a separate inlet valve so that they can be filled independently. The system was also designed with bottom outlet valves to allow each pond to be drained into the lake and cleaned as necessary. The main and secondary brood stock ponds along with the commercial pond for grown tilapia were designed with surface drains. These drains lead to the grow-out pond so fingerlings can mature in a nutrient-rich environment that encourages growth.

\section{Engineering Design}

The initial step involved in transporting water from the Ba Cange dam to the fish hatchery was to direct the water from the dam into pipes. CEDC students began by designing a spool piece that could attach securely to the 6" PVC flange at the bottom of the dam, while providing for several connections to water lines that could route water towards the ACEDLP hatchery. As seen in Figure 6, the spool piece contains more connections than necessary to allow for further expansion or even irrigation lines for local farms. The spool was fabricated by a professional welder in the United States and shipped to Haiti in 2014. It was installed in Spring 2015 and can be seen in Figure 6. As shown, a concrete block structure was constructed below the galvanized metal spool to limit the stress on the PVC flange.

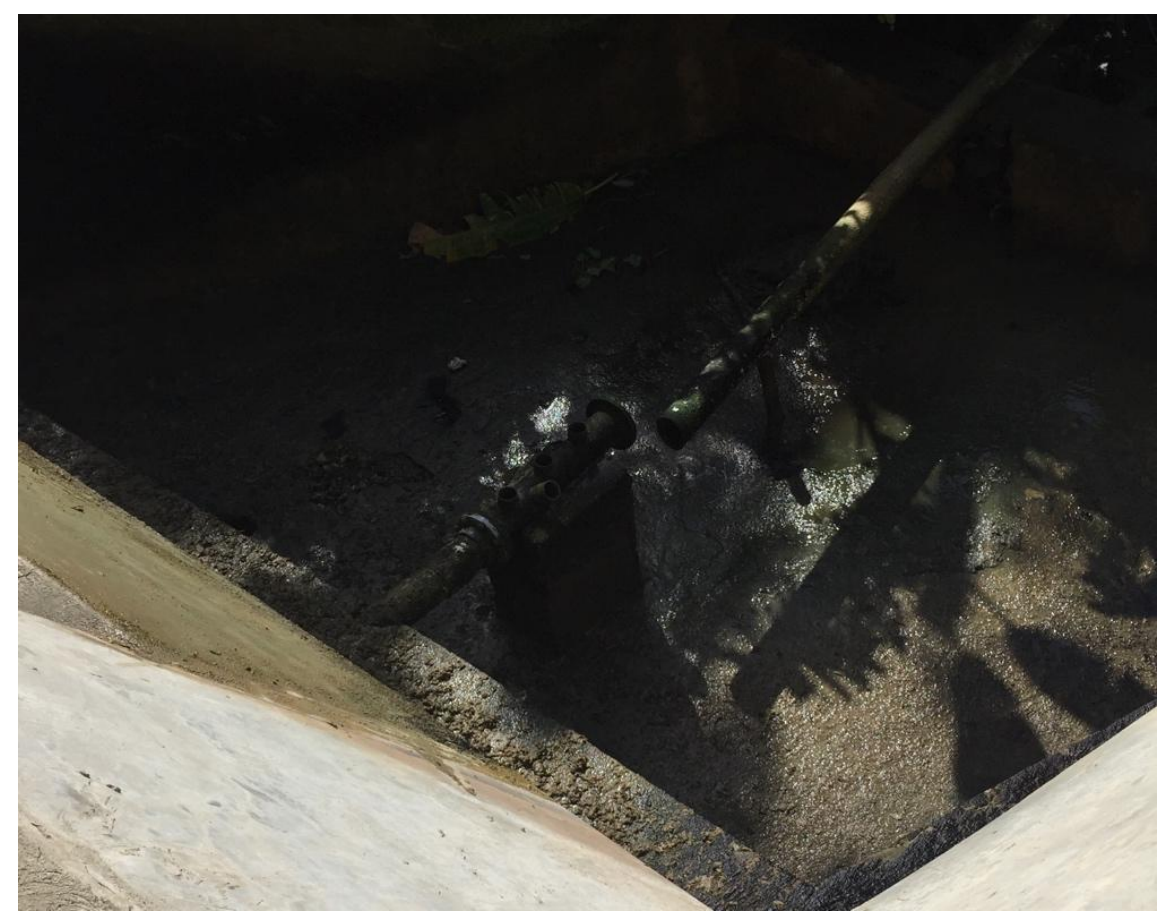

FIGURE 6

THE INSTALLED SPOOL PIECE WITH THE REMNANTS OF THE PVC NEXT TO IT 
International Journal for Service Learning in Engineering, Humanitarian Engineering and Social Entrepreneurship Vol. 12, No. 2, pp. 15-33, Fall 2017

ISSN 1555-9033

The next design challenge involved connecting a galvanized pipe from the spool at the dam to the hatchery ponds, while crossing a 10-foot-wide stream in a deep ravine. CEDC students originally planned to cross the stream using a three-dimensional truss. Each of the galvanized pipes carrying water to the hatcheries could be connected with \#5 rebar bent at ninety degree angles via stainless steel U-bolts. All these materials are available in Haiti and the innate integrity of the truss design could ensure that the span would be structurally sound. However, after consulting with local Haitians and industry engineers about the design, students decided against it. There was concern that the truss would be used by locals as a foot bridge regardless of whether or not it is designed for these live loads. To construct a bridge that could protect the water lines while accounting for potential pedestrian loads, a new design was needed.

CEDC students then evaluated a reinforced concrete suspension bridge. This structure could allow for the protection of the water lines while also being the most cost-effective and easiest to construct. The structural integrity of properly designed and constructed stanchions could handle pedestrian traffic in addition to potential environmental abuses, such as heavy rains. In addition, the bridge would make commuting to school and work much easier for the locals, thereby adding another dimension to the project. The American Association of State Highway and Transportation Officials (AASHTO) design guidelines for pedestrian footbridges were used to calculate live loads. ${ }^{45}$ The final profile view of the bridge and pipeline can be seen in Figure 7.

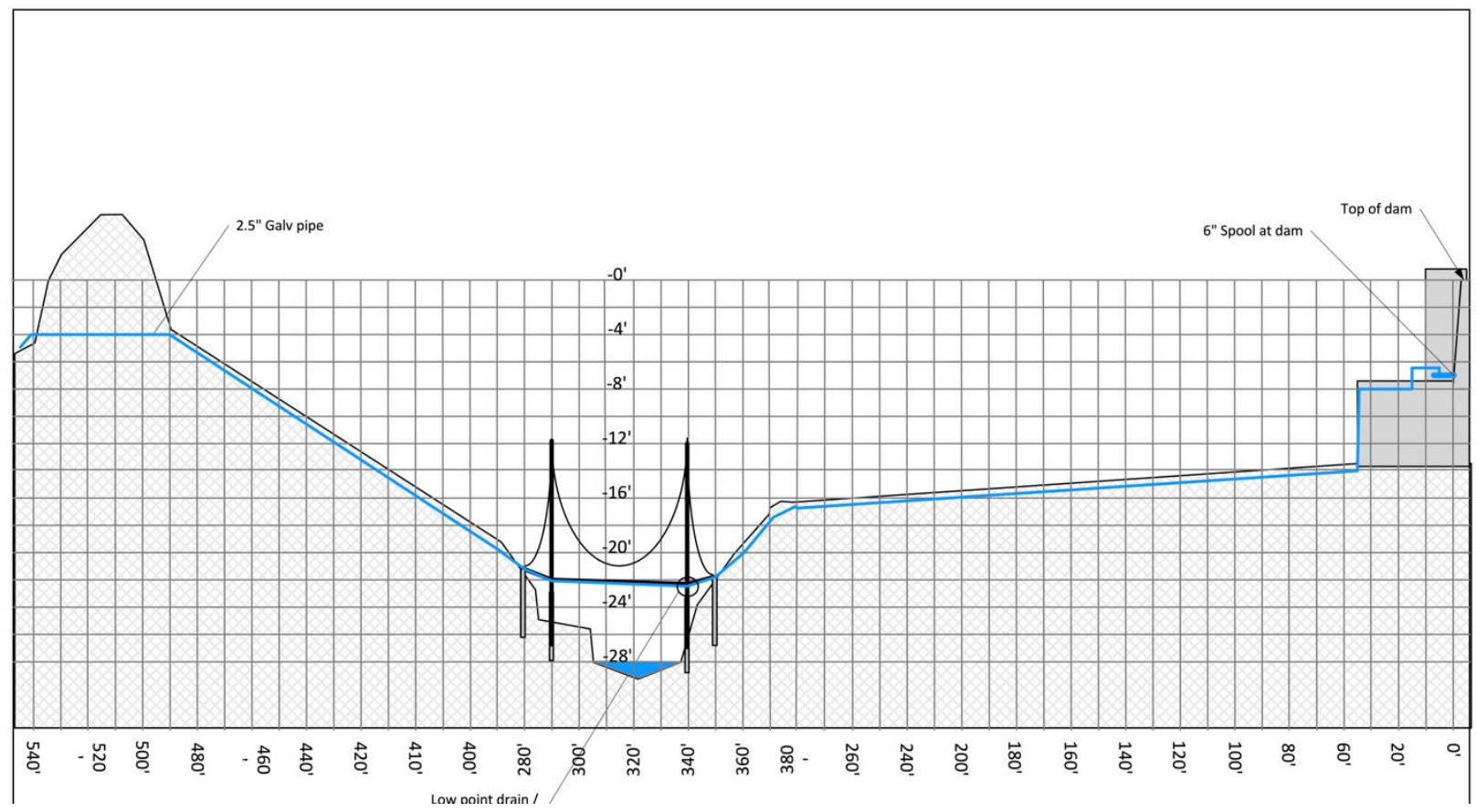

FIGURE 7

PROFILE VIEW OF THE DESIGNED WATER LINE TO THE ACEDLP. BRIDGE DIMENSIONS ARE NOT DRAWN TO SCALE 


\section{IMPLEMENTATION}

\section{Construction and $M O U$}

Prior to construction, CEDC and ACEDLP developed and signed a memorandum of understanding (MOU). This document outlined the responsibilities of both parties. CEDC students and advisors agreed to design a system that could carry water from the dammed spring to the ACEDLP ponds, supervise the engineering and construction of the design, and manage the project until ACEDLP commissioned the system. ACEDLP agreed to provide labor for construction (namely excavation for the pipeline), follow CEDC's design during construction, and assume ownership of the system after commission.

CEDC student interns managed and oversaw the construction of the project. They worked with a local foreman to plan out the steps in construction of the bridge and pipeline. After developing a three-month plan for the project, work commenced. It began with the fabrication of parts for the bridge stanchions by a local welder. In addition, raw materials and equipment were hauled down to the construction site, including a cement mixer, and galvanized piping used as bridge supports acquired from Port-au-Prince. CEDC student interns provided daily progress reports to CEDC industry advisors as construction began. While student interns operated as project managers, all workers on the project, from foremen to masons to diggers, were local Haitians who served to benefit from the successful execution of the project. This structure is typical of most CEDC projects, ${ }^{46}$ and construction was completed on schedule within three months.

\section{Completion}

When the water line was completed in November 2015, Caribbean Harvest began training and educating local technicians about maintaining the new hatchery. Instead of using the designed flow through system, which involved a steady flow of water passing through each individual pond to generate aeration, ACEDLP and Caribbean Harvest opted to partially open the gate valves to spray water into each pond which aerated the water for a short time each day. Using this approach, the need for a flow system was unnecessary; thus, minimizing water usage.

This project was undertaken in close collaboration with ACEDLP members so that they would know how to maintain and upkeep the system of pipes. Because the fish that are going to be grown in the ponds will generate revenue, ACEDLP will have the resources to maintain the pipeline and bridge. When the project was completed, the CEDC interns officially walked ACEDLP through the project so that they understood how the pipes operated and how the valves could be manipulated.

\section{Hatchery Operations}

After training with Caribbean Harvest and being educated on the water system operation, ACEDLP stocked one of the ponds with 120 brooders. Fry were then collected and distributed to one of the other ponds. As of August 2016, these two ponds housed over 1,000 fingerlings each, and it is expected that at capacity this hatchery could produce 20,000 to 30,000 fingerlings with this setup. The red tilapia fingerlings can be seen in Figure 8. 


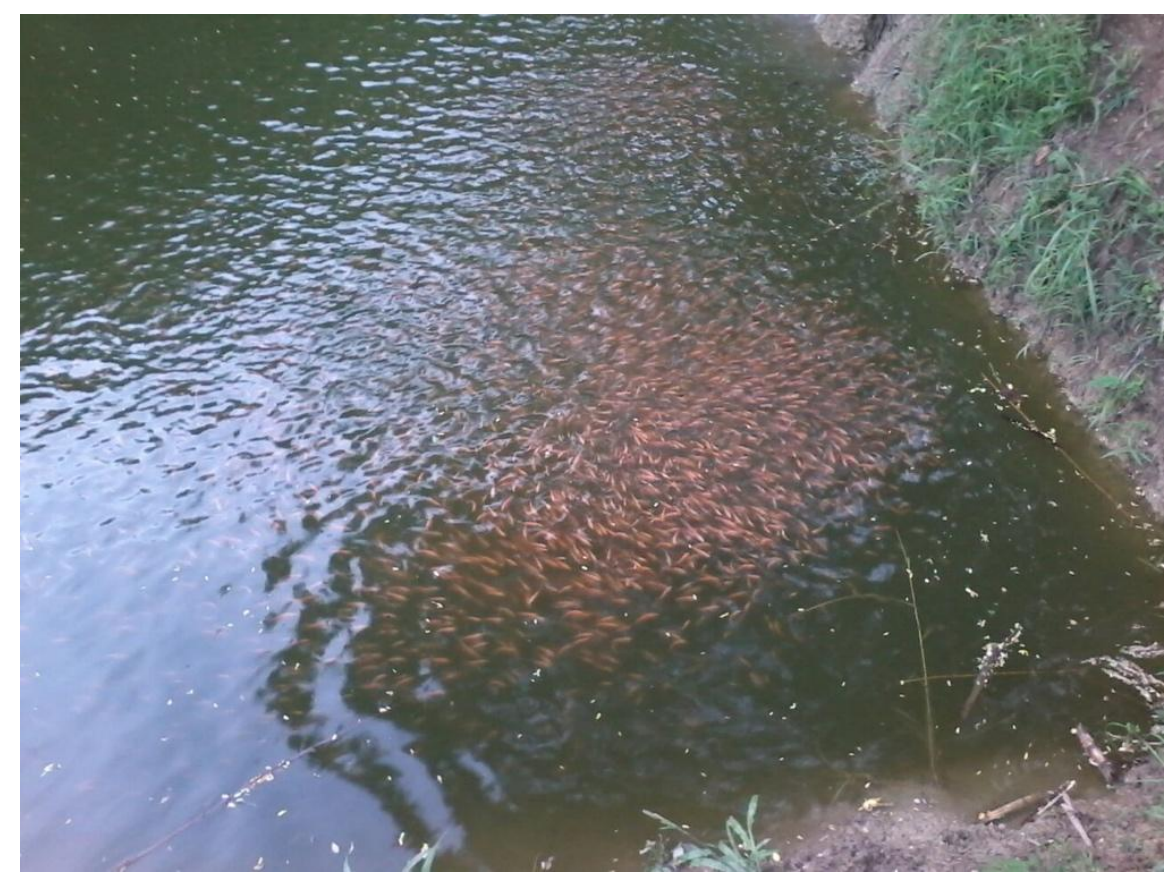

FIGURE 8

TILAPIA FINGERLINGS IN THE NEW ACEDLP HATCHERY

At the beginning of the fishing season in Fall 2016, ACEDLP had selected sixty families to receive one cage with 1,500 fingerlings from this new hatchery. Under the supervision of ACEDLP, these families will tend the cages and sell the fish in Cange and other local villages around the lake. The profits will be split amongst the family, ACEDLP, and Caribbean Harvest so that these local NGOs can reinvest in the hatchery and grow the enterprise. The profits will be used by ACEDLP to expand the program and reach more families.

For feed, Caribbean Harvest and ACEDLP import complete floating feed from Valdosta, GA. Many other aquaculture operations in Haiti also acquire their feed from this source, including all of Caribbean Harvest's feed. ${ }^{47}$ Fish feed is one of the largest obstacles facing commercial aquaculture in Haiti, but the system organized by these programs has worked well to this point. ${ }^{48}$ Regardless, feed accounts for about half of the production cost for the Caribbean Harvest enterprise. $^{49}$

The bridge has also been very popular as a thoroughfare among the residents of Ba Cange. The finished product can be seen in Figure 9. Children use the bridge every day to get to school, and men and women use it daily while collecting food and traveling to their other plots. The citizens themselves have highlighted how the convenience and safety of the bridge have drastically improved their quality of life by allowing them to easily and quickly cross the stream and the ravine. 


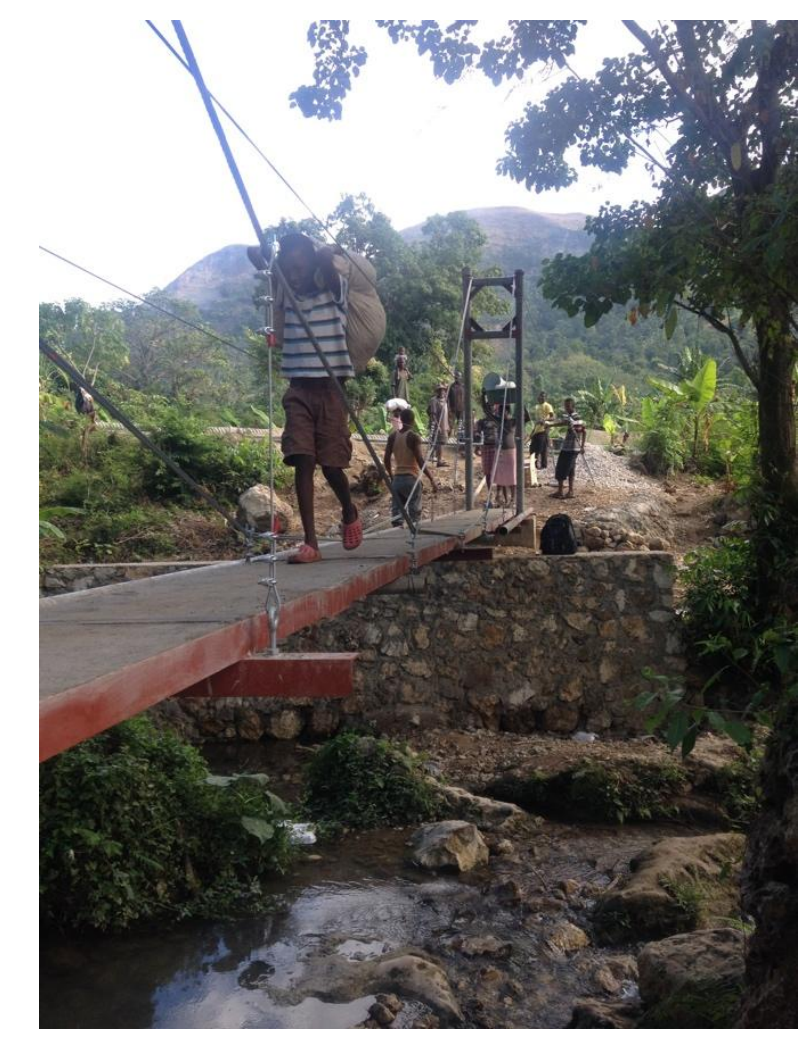

FIGURE 9

HAITIANS USING THE FINISHED SUSPENSION BRIDGE

\section{DISCUSSION}

As the result of partnerships with CEDC, EDUSC, and Caribbean Harvest, ACEDLP was able to establish a successful aquaculture hatchery and improve the economic infrastructure in the area. The project used materials predominantly found in the Central Plateau and constructed a hatchery through a local Haitian-run organization that can coordinate with local farmers, which is a better method to develop local economies. ${ }^{50}$ Moreover, the gravity-fed system and gate valves for aeration make electricity unnecessary for hatchery operations.

Once this basic level of infrastructure was met through the dammed spring, waterline, and bridge, aquaculture in the area has flourished. Another local entrepreneur has started constructing aquaculture ponds and will be using ACEDLP's water line, as seen in Figure 10. This large operation is funded by local Haitian businessmen with little to no international involvement. The enterprise purchased their galvanized piping, and requested that CEDC student interns oversee the connection and installation of the water line to ensure a safe and long-lasting system. Furthermore, the designed spool piece at the dammed spring has two additional connections that could be used for future water lines by other organizations or businesses. 


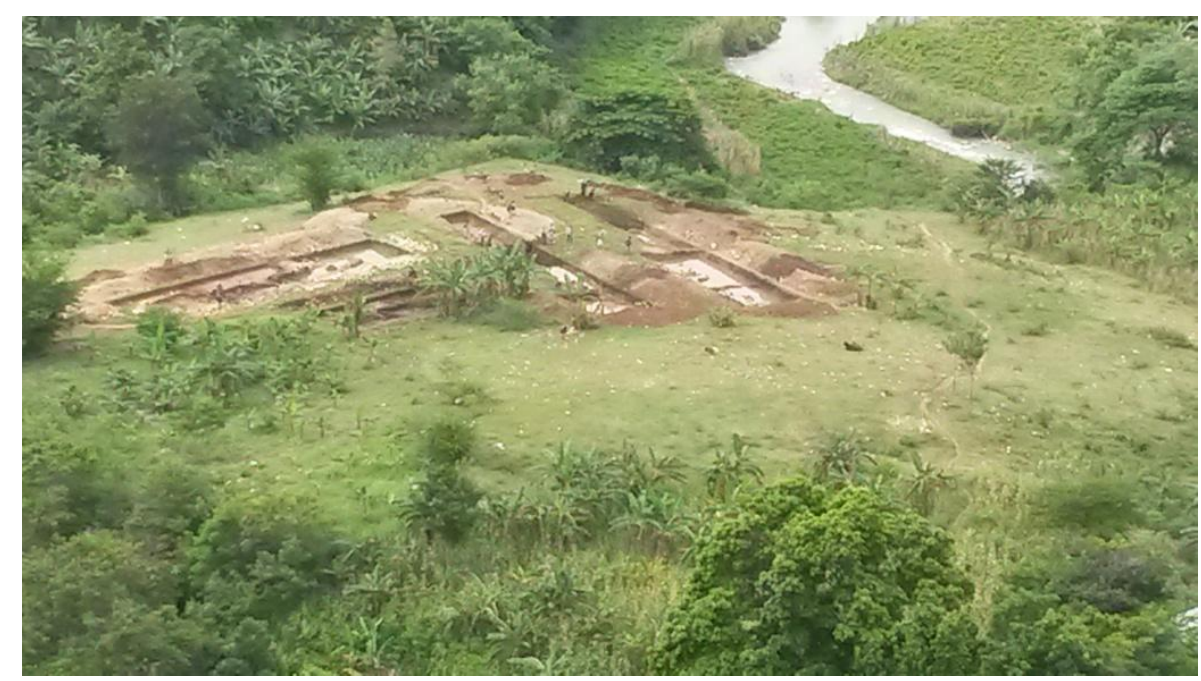

FIGURE 10

NEW AQUACUlture OPERATION IN BA CANGE

Undergraduate students were heavily involved in this project from start to finish. In fact, through CEDC, students first identified ACEDLP as a potential partner and student interns met with ACEDLP representatives weekly during the course of the project. Nearly twenty students were involved, either through research at Clemson University, designing and engineering the bridge and hatchery layout, or overseeing construction in Haiti. The student interns were able to interact with the entire Cange and Ba Cange communities as well as Haitian culture during the project through the immersive CEDC internship program. ${ }^{51}$ While only a handful of students were able to see the project from inception to completion, all other students were able to take part in the process and learn about project management, engineering design, and client relations in industry.

Unlike previous efforts by the Food and Agriculture Organization (FAO) and OB, this venture represented a grassroots approach towards economic development via aquaculture. The idea was realized by students at Clemson University but conceived by ACEDLP who took full control of the operation, maintenance, and accounting of the enterprise with support from Caribbean Harvest. While the FAO offered technology and fish during their efforts in the mid$20^{\text {th }}$ century, Caribbean Harvest's partnership with aquaculture programs on Lake Peligre can offer the sort of the long-term support that the FAO's unsuccessful programs lacked. Additionally, while OB's centralized fish hatchery offers farmers resources to start their own program, the decentralization and accessibility of ACEDLP's hatchery offer local farmers a much easier, cheaper, and convenient location to get their resources. Contrary to the hatchery at Caribbean Harvest near Boucan-Carre, the simple technology and renewable nature of ACEDLP's hatchery enable the technicians to independently and responsibly operate the facility. The ACEDLP hatchery was built by Haitians and for Haitians.

Despite these small improvements to infrastructure in the area, aquaculture still faces several obstacles, including a lack of locally produced fish feed. Many organizations, including the Marine Biological Laboratory (MBL), have researched local alternative feeds for use in Haiti and other developing countries. Such studies and reviews demonstrate that the dearth in affordable and locally produced fish feed in both Haiti, Sub-Saharan Africa, and other poverty-stricken 
states is a major factor that precludes aquaculture from achieving scalability, sustainability, and affordability. ${ }^{52}$ Additionally, the paucity of microfinance and loan-granting institutions in the Central Plateau serves as a major hurdle to Haitians seeking to begin their own fishery on Lake Peligre. While ACEDLP hopes to grow their program to as many families and individuals as possible, there is still room for improvement. CEDC students are now researching ways to provide locally sourced and affordable fish feed in addition to potential partnerships with microfinance organizations in the Central Plateau.

More research must be conducted to fully assess the extent of the success of ACEDLP's and Caribbean Harvest's particular program. Even though this endeavour has had a promising start, more data must be collected in the coming years in order to provide a fully objective and just evaluation. Past experiences with fisheries in Haiti has had mixed results due to the erratic nature of fishery cash flow. ${ }^{53}$ ACEDLP's profit-sharing program may be able to circumvent this challenge and help encourage a steadier cash flow for the locals. Even though fisheries may lead to a decrease in a region or country's overall poverty, it may concurrently increase inequalities in the area, leading to no overall increase in quality of life for the local citizens. This relationship has been identified in the past with economic development programs. ${ }^{54}$ Especially in close-knit communities in the Central Plateau such as Cange, longitudinal assessments must be conducted to determine the trade-offs of a certain action or project. ${ }^{55}$

Environmental assessments should also be performed around Lake Peligre to professionally evaluate its aquaculture potential. Inland fisheries can have several negative impacts on the environment if not managed properly, including straining local water supplies, promoting soil erosion, and wasting precious nutrient resources. ${ }^{56}$ While most of these problems are associated with more intensive and commercial enterprises, efforts should still be made to educate ACEDLP and other local farmers about unsustainable practices that may disproportionally damage the local environment. ${ }^{57}$ Fortunately, CEDC's internship and sustained presence in Cange will allow continuous education and monitoring of the hatchery to mitigate this problem.

\section{CONCLUSION}

A World Bank report on rural development in Haiti suggested that diversifying agricultural production and livelihood by fostering non-farm opportunities is a major way to promote economic development and food security. ${ }^{58}$ Implementing a successful aquaculture program has the power accomplish these goals but requires several considerations involving the social, environmental, economic, and institutional consequences. ${ }^{59}$ In this case study, a local Haitian organization began this process with a small initial investment by an NGO and support from a team of students and engineers at Clemson University. The results of this new infrastructure has yielded a new hatchery and several fish ponds that are technically sound and engineered to established standards. The construction practices and partnership structures used here can be replicated by other NGOs around Haiti and other low-resource settings in order to realize similar positive outcomes for aquaculture enterprises. 
International Journal for Service Learning in Engineering, Humanitarian Engineering and Social Entrepreneurship Vol. 12, No. 2, pp. 15-33, Fall 2017

ISSN 1555-9033

\section{ACKNOWLEDGMENT}

The authors would like to acknowledge the Episcopal Diocese of Upper South Carolina, Jackie Williams, Caribbean Harvest, and ACEDLP for their support of this academic endeavour. In addition, Clemson Engineers for Developing Countries and this research is made possible by Clemson University Creative Inquiry program and the Office of Global Engagement.

\footnotetext{
${ }^{1}$ Food \& Agriculture Organization (FAO). 2016. "State of World Fisheries and Aquaculture." United Nations. Accessed September 2016. http://www.fao.org/3/a-i5555e.pdf

${ }^{2}$ Matsuda, Yoshiaki. 1978. "The Growth of Aquaculture in Developing Countries: Potentials, Patterns and Pitfalls." Fisheries 3 (4).

${ }^{3}$ Hargreaves, John A., Craig Browdy, Bill Mebane, Dave Conley, and Valentin Abe. 2012. "Developing Tilapia Aquaculture in Haiti: Opportunities, Constraints, and Action Items." Proceedings of a workshops sponsored by NOVUS International, Aquaculture without Frontiers, the World Aquaculture Society, and the Marine Biological Laboratory. New Orleans: Aquaculture Assessments.

${ }^{4}$ Food \& Agriculture Organization (FAO). 2016. "State of World Fisheries and Aquaculture.” United Nations.

${ }^{5}$ Lampe, Harlan, Nelson Marshall, Jon Sutinen, Lars Vidaeus, and Deborah Westin. 1974. "Prospects for Fisheries Development Assistance.” International Center for Marine Resource Development. 19.

${ }^{6}$ Food \& Agriculture Organization (FAO). 2016. "State of World Fisheries and Aquaculture." United Nations.

${ }^{7}$ Ahmed, M. and Lorica, M. 2002. "Improving developing country food security through aquaculture development: Lessons from Asia.” Food Policy. 27(1): 125-141.

${ }^{8}$ Hishamunda, Nathanael. and Neil Ridler. 2006. "Farming fish for profits: A small step towards food security in sub-Saharan Africa.” Food Policy, 31: 401-414.

${ }^{9}$ Griggs, David. 2013. "Sustainable development goals for people and planet.” Nature. 495: 305-307.

${ }^{10}$ Crespi, Valerio. 2011. "Promotion and Development of Freshwater Aquaculture in Haiti." Food and Agriculture Organization Newsletter. 47:12-15.

${ }^{11}$ Wurmann, Carlos G. 2017. "Regional Review on Status and Trends in Aquaculture Development in Latin America and the Caribbean.” Food and Agriculture Organization Fisheries and Aquaculture Circular. C1135/5: III,IV,V,1-36.

${ }^{12}$ World Bank. 2014. Investing in people to fight poverty in Haiti. World Bank Group, World Bank Group.

${ }^{13}$ Coello, B., Oseni, G., Savrimootoo, T. and Weiss, E. 2014. "Rural development in Haiti." The World Bank. Accessed September 2016. http://documents.worldbank.org/curated/en/976171468032682306/pdf/955400WP0Box390portunities00PUBLIC0.p df

${ }^{14}$ Food \& Agriculture Organization (FAO). 1980. “Aquaculture Development in Caribbean.” United Nations. Accessed September 2016. http://www.fao.org/docrep/006/p4495e/p4495e04.htm
} 
International Journal for Service Learning in Engineering, Humanitarian Engineering and Social Entrepreneurship Vol. 12, No. 2, pp. 15-33, Fall 2017

ISSN 1555-9033

${ }^{15}$ Food \& Agriculture Organization (FAO). 2016. "State of World Fisheries and Aquaculture." United Nations.

${ }^{16}$ Coello, B., Oseni, G., Savrimootoo, T. and Weiss, E. 2014. "Rural development in Haiti." The World Bank.

${ }^{17}$ Hargreaves, John. 2012. "Developing Tilapia Aquaculture in Haiti: Opportunities, Constraints, and Action Items."

${ }^{18}$ Food \& Agriculture Organization (FAO). 2016. "State of World Fisheries and Aquaculture.” United Nations.

${ }^{19}$ Brass, Jane L., Bori L. Olla, and Robert I. Wicklund. 1991. "Social, Economic, and Cultural Considerations for Saltwater Cage Culture of Florida Red Tilapia in Northeastern Haiti." Proceedings of the Gulf and Caribbean Fisheries Institute. Gulf and Caribbean Fisheries Institute. 398-404.

${ }^{20}$ Food \& Agriculture Organization (FAO). 1980. “Aquaculture Development in Caribbean.” United Nations.

${ }^{21}$ Masterson, J. 2007. Oreochromis mossambicus. Smithsonian Marine Station. December 1. Accessed 2016. http://www.sms.si.edu/irlspec/Oreochromis_mossambicus.htm.

${ }^{22}$ Lovell, R. T., R. O. Smitherman, and E. W. Shell. 1976. Progress and prospects of fish farming. Department of Fisheries and Allied Agriculture, Auburn University, Washington, DC: United States Agency for International Development, 39.

${ }^{23}$ Smitherman, R. Oneal. 1973. "Technical Assistance in Freshwater Fisheries Development in Haiti." International Center for Aquaculture, Auburn University, Auburn.

${ }^{24}$ Hargreaves, John. 2012. "Developing Tilapia Aquaculture in Haiti: Opportunities, Constraints, and Action Items."

${ }^{25}$ Landell Mills. 2012. Strategic Assessment of Aquaculture Potential in Haiti. ACPFish II. http://acpfish2 eu.org/uploads/projects/id153/Final\%20Technical\%20report\%20CAR-3.1-B12.pdf

${ }^{26}$ Hargreaves, John. 2012. "Developing Tilapia Aquaculture in Haiti: Opportunities, Constraints, and Action Items."

${ }^{27}$ Smitherman, R. Oneal. 1973. "Technical Assistance in Freshwater Fisheries Development in Haiti." International Center for Aquaculture, Auburn University, Auburn.

${ }^{28}$ Food \& Agriculture Organization (FAO). 1980. “Aquaculture Development in Caribbean.” United Nations.

${ }^{29}$ Chounoune, Jackson. 1998. "Some fisheries and aquaculture projects in Haiti." EC Fisheries Cooperation Bulletin, 11(1). Accessed September 10. http://ec.europa.eu/development/body/publications/fish/pe039823.pdf

${ }^{30}$ Clinton Foundation, 2012. "Caribbean Harvest.” Accessed August 2016.https://www.clintonfoundation.org/ourwork/clinton-foundation-haiti/programs/caribbean-harvest

${ }^{31}$ Snow, Erin. 2012. Cage Fishing Project Improves Output in Haiti. Accessed August 2016. http://www.heifer.org/join-the-conversation/blog/2012/November/cage-fishing-project-improves-output-inhaiti.html.

${ }^{32}$ Landell Mills. 2012. Strategic Assessment of Aquaculture Potential in Haiti.

${ }^{33}$ Landell Mills. 2012. Strategic Assessment of Aquaculture Potential in Haiti.

${ }^{34}$ Matsuda, Yoshiaki. 1978. "The Growth of Aquaculture in Developing Countries: Potentials, Patterns and Pitfalls." 
International Journal for Service Learning in Engineering, Humanitarian Engineering and Social Entrepreneurship Vol. 12, No. 2, pp. 15-33, Fall 2017

ISSN 1555-9033

${ }^{35}$ Lovell, R. T. 1976. Progress and prospects of fish farming. Department of Fisheries and Allied Agriculture, Auburn University, Washington, DC: United States Agency for International Development, 39

${ }^{36}$ Ogle, Jennifer, Jeffery Plumblee, David Vaughn, and Aaron Gordon. 2016. "Enhancing Student's Learning Experiences through Translational Research in Multidisciplinary Engineering Education." 2016 ASEE Annual Conference and Exposition.

${ }^{37}$ Bargar, D., Gordon, A., Plumblee, J., Ogle J., Dancz, C., and Vaughn, D. 2016. "Increasing student development through multi-level immersive learning: Clemson Engineers for Developing Countries case study." International Journal of Service-Learning Education, Humanitarian Engineering, and Social Entrepreneurship (IJSLE).

${ }^{38}$ Gordon, Aaron, Jeffery Plumblee, and Claire Dancz. 2017. "Autoethnographical reflections of an immersive development engineering program." ASEE Zone II Conference.

${ }^{39}$ Gordon, Aaron, Jeffery Plumblee, and David Vaughn. 2017. "Developing Rural Water Systems in Haiti: An Evaluation of the First Chlorinated Municipal Water System in the Central Plateau." Journal of Humanitarian Engineering 5 (1).

${ }^{40}$ Gordon, Aaron, Plumblee, Jeffery, Dimarco, Kayla, Vaughn, David, and Jennifer Ogle. 2016. "Partnership to improve the quality of local construction materials in Haiti's Central Plateau." Journal of Humanitarian Engineering. 4(2).

${ }^{41}$ Ogle, Jennifer, Jeffery Plumblee, David Vaughn, and Aaron Gordon. 2016. "Enhancing Student's Learning Experiences through Translational Research in Multidisciplinary Engineering Education." 2016 ASEE Annual Conference and Exposition.

${ }^{42}$ Gordon, Aaron, Jeffery Plumblee, and David Vaughn. 2017. "Developing Rural Water Systems in Haiti: An Evaluation of the First Chlorinated Municipal Water System in the Central Plateau." Journal of Humanitarian Engineering 5 (1).

${ }^{43}$ Page, J., and Pierce Williams. 1983. Engineering Feasibility Study and Report on Engineering Work Trip. The Episcopal Diocese of Upper South Carolina.

${ }^{44}$ Pedley, S., K. Pond, and E. Joyce. 2011. "Interventions for Water Provision." In Valuing Water, Valuing Livelihoods, by J. Cameron and P. Hunter. World Health Organization.

${ }^{45}$ American Association of State Highway and Transportation Officials (AASHTO). 2009. LRFD Specifications for the Design of Pedestrian Bridges. Washington, DC: AASHTO.

${ }^{46}$ Bargar, D., Gordon, A., Plumblee, J., Ogle J., Dancz, C., and Vaughn, D. 2016. "Increasing student development through multi-level immersive learning: Clemson Engineers for Developing Countries case study." International Journal of Service-Learning Education, Humanitarian Engineering, and Social Entrepreneurship (IJSLE).

${ }^{47}$ Hargreaves, John. 2011. "Tilapia Aquaculture in Haiti.” Aquaculture without Frontiers. http://www.mbl.edu/sai/files/2012/05/Hargreaves-April-2011-Trip-Report.pdf

${ }^{48}$ Hargreaves, John. 2012. "Developing Tilapia Aquaculture in Haiti: Opportunities, Constraints, and Action Items."

${ }^{49}$ Hargreaves, John. 2011. “Tilapia Aquaculture in Haiti.” Aquaculture without Frontiers.

${ }^{50}$ Wilson, Patricia A. 1995. "Embracing Locality in Local Economic Development." Urban Studies 32 (4-5): 645658. 
International Journal for Service Learning in Engineering, Humanitarian Engineering and Social Entrepreneurship Vol. 12, No. 2, pp. 15-33, Fall 2017

ISSN 1555-9033

${ }^{51}$ Gordon, Aaron, Jeffery Plumblee, and Claire Dancz. 2017. "Autoethnographical reflections of an immersive development engineering program." ASEE Zone II Conference.

${ }^{52}$ Gabriel, U., Akinrotimi, O., Bekibele, D., Onunkwo, D. and Anyanwu, P. 2007. "Locally produced fish feed: potentials for aquaculture development in subsaharan Africa." African Journal of Agricultural Research, 2(7): 287295.

${ }^{53}$ Brass, Jane. 1991. "Social, Economic, and Cultural Considerations for Saltwater Cage Culture of Florida Red Tilapia in Northeastern Haiti."

${ }^{54}$ Ravillion, M. 1995. "Growth and Poverty: Evidence for developing countries in the 1980s." Economics Letters 48 (3): 411-417.

${ }^{55}$ Worley, Natalie. 2015. Objective and Subjective Correlates of Quality of Life in Rural Haiti. PhD Dissertation, Clemson University, Clemson: Clemson University.

${ }^{56}$ Pullin, R. 1993. An Overview of Environment and Aquaculture in Developing Countries. Vol. 31, in Environment and Aquaculture in Developing Countries, by R. Pullin, H. Rosenthal and J.L. Maclean, 359. ICLARM Conference Proceedings.

${ }^{57}$ Beveridge, M., Phillips, M. and Macintosh, D. 1997. "Aquaculture and the environment: the supply of and demand for environmental goods and services by Asian aquaculture and the implications for sustainability." Aquaculture Research, 28(10): 797-807.

${ }^{58}$ Coello, B., Oseni, G., Savrimootoo, T. and Weiss, E. 2014. "Rural development in Haiti." The World Bank.

${ }^{59}$ Lazard, J., Rey-Valette, H., Aubin, J., Mathé, S., Chia, E., Caruso, D., Mikolasek, O. 2014. “Assessing aquaculture sustainability: a comparative methodology.” International Journal of Sustainable Development \& World Ecology. 21(6): 503-511. 